ciple admits the possible existence of heavier nuclei, but declares that it is impossible for atoms of higher number, built on the Rutherford model, to exist with their full complement of electrons. If the laws we discover in physics hold in all parts of the universe, we deduce that there is this definite limit to the number of elements existing. This is an interesting conclusion, and it is remarkable that the number falls so close to the number of elements at present known, namely, 92. The principle behaves here as a condition of stability, and it may be that elements of higher number than 92 are extremely unstable, and now remain only in minute quantities.
This question of the maximum number of elements possible has been discussed by V. V. Narliker in Nature for March 12, p. 402; 1932. The notation and method of Sir Arthur Eddington have been applied, and from considerations of invariance the maximum number obtained is 92 .

The unitary theory and uncertainty principle deduced from it indicate that observers in space and time will discover both space and time are discontinuous, for their measurements of intervals of length and time will always be in integral multiples of $\Delta l$ and $\Delta t$. The method of arriving at this conclusion indicates that this discontinuity underlies the old quantum theory.
H. T. FLINT.

\title{
Sir Charles Parsons and his Work
}

" QAVERY, Newcomen, Smeaton, the famous Watt, Woolf, Trevithick, and some other English engineers were the veritable creators of the steam engine," said Sadi Carnot in his essay of 1824, while a year ago the Engineer, on the occasion of the death of Sir Charles Parsons, remarked that " to Great Britain belongs the credit for the origination of nearly all the fundamental inventions for the production and industrial utilisation of heat energy"

Although during the nineteenth century many improvements in heat engines, more especially in internal combustion engines, were made abroad, it remains true that it is in the records of the British Patent Office that most of the outstanding inventions made in connexion with steam engines and steam turbines are to be found. With the steam turbine will ever be associated the name of Sir Charles Parsons, who, as Sir Alfred Ewing said when lec. turing on the work of Parsons at the Royal Institution last November, "was incomparably the most illustrious and most revolutionary engineer of his time ". In view of the long and close friendship of Sir Alfred with Parsons, it was almost inevitable that on the occasion of this lecture, an account of which has recently been published, he should pay a tribute to him not only as an engineer but also as a friend. He therefore addressed his remarks not so much to those familiar with the steam turbine and its development, as to those who wished to know more of what Parsons did and how he did it, and what manner of man he was that he should be ranked so confidently among famous men.

Allowing for differences in time and circumstances, there is a remarkable similarity between the work done by Watt and by Parsons, and what the latter said of his great forerunner might well be applied to himself. When delivering the second Joule memorial lecture to the Manchester Literary and Philosophical Society in 1922, Parsons said: "James Watt's conclusions appear to have been the result of close and patient reasoning of a mind endowed with extraordinary powers of insight into physical questions, and of drawing sound practical conclusions from numerous experiments devised to throw light on the subject under consideration".

In his early surroundings, Parsons was even more fortunate than Watt, and his boyhood was spent in an atmosphere calculated to stimulate to the highest degree his interest in science and the mechanical arts. His father, by his construction of the famous reflecting telescope, had made Birr Castle the 'Mecca' of astronomers all over the world, while his mother possessed manipulative skill of no mean order. His tutors, too, were men of the highest calibre. In its influence on its various members, the home at Birr may well be compared to that of the Darwins at Downe. From it, Parsons emerged one of the most industrious of men, but also one of the shyest, and the effects of his unconventional boyhood remained stamped on him for life. It was his natural reserve and modestycharacteristics possessed by few inventors-which puzzled strangers. "His hesitating, fragmentary speech, his passive hand-shake, his somewhat shrinking manner," said Sir Alfred, "gave at first an impression of ineffectiveness which completely belied the latent force, the precision of purpose, the resolution that treated obstacles only as incentives to further effort, the fertility of invention that never accepted defeat."

Of Parsons' invention and development of the steam turbine, it may be said it was a piece of creative work comparable to that of a great writer or artist. Moreover, it was one for which the time was ripe, and which immediately and successfully fulfilled its purpose. The slow-speed reciprocating engines developed from the original inventions of Newcomen and Watt were ill adapted for driving the electric generators which were just coming into use when Parsons started work, and he was but one of many who attacked the problem of high speed. De Laval solved it one way and Parsons another. Thanks to the authorities at the Science Museum, Sir Alfred was able to exhibit at his lecture the historic turbo-generator Parsons made in 1884 and exhibited in the Inventions Exhibition of 1885. Running at the extraordinary speed of 18,000 revolutions a minute, the turbine drove an armature of only $2 \frac{5}{8} \mathrm{in}$. diameter, the construction of which displayed as much ingenuity as the turbine itself. It was not mentioned by Sir Alfred, and it is little known, that among the important novelties in this machine was a system of forced lubrication. 
At first the Parsons turbine was used without a condenser and was " a notorious steam eater". How Parsons brought in the compound turbine, the condensing turbine, the marine turbine, and the geared turbine, and how he successfully attacked the many problems which arose as the turbine gradually superseded steam engines in powerhouses and ships, Sir Alfred made clear with the help of lantern slides, but unfortunately the report of his lecture has no illustrations.

It was once said that the work of Parsons had halved the cost of generating electricity. That is probably well within the mark. The relative importance of turbine plant to-day is shown by the official statistics quoted by Sir Alfred, "British power-stations in 1930 ", he said, " show that steam turbines provided more than $5 \frac{1}{2}$ million kilowatts, while all the other types of heat engines accounted for less than a quarter of a million." But neither the generation of power nor the propulsion of ships monopolised the activities of Parsons. He spent much time and money in the attempt to produce artificial diamonds, worked out a scheme for boring a shaft in the earth's crust 12 miles deep, studied the casting of large steel ingots, and in his later years turned to the subjects which had engrossed his father and became a maker of optical glass and a constructor of large telescopes. No one to-day doubts that he was the most illustrious engineer of his time, and a biography of him should prove of the greatest value to students of both science and engineering.

\section{The Great Barrier and the Formation of Coral Reefs}

$\mathrm{D}^{\mathrm{R}}$ R. YONGE divided the plan of operations of the Great Barrier Reef Expedition into four sections: (1) the detailed study of the feeding of corals; (2) the plankton and sea-water; (3) an ecological study of corals and associated organisms ; and (4) the examination of the bottom flora and fauna, with the determination of the zoning of life at increasing depths (NATURE, 121, 213; 1928). The British Museum (Natural History) has now commenced to publish the results in these four sections. Dr. Yonge's own work is mainly included in vol. 1 and has been already sufficiently summarised in NaTuRE, 12\%, $309 ; 1931$. It is a very remarkable study of the feeding of corals, from which he concludes that symbiotic algæ are "an indispensable factor in the necessarily exceptional powers of growth and repair possessed by the marine communities known as coral reefs ". This is as much as concerns the student of the formation of coral reefs.

The methods for the collecting of zooplankton, designed mainly by F. S. Russell, require careful study, but comment is deferred until some quantitative and qualitative results are published. There were 189 hauls of the nets at 68 stations, together with a series of reef-flat plankton collections. For comparative purposes it would be useful if future marine expeditions adopted similar methods. The number of new species of animals obtained in the plankton may be small, the geographical region being the tropics, but the wealth of the collections is indicated in Mr. Barnard's "Amphipoda", more than a thousand specimens ( 23 species) of Hyperiidea having been submitted to him for examination.

Vol. 3 contains papers relating to the structure and ecology of reefs. J. A. Steers's geographical introduction is intended for biologists who deal "with definite facts" while geographers "deal with theory". He might have added that biologists on this expedition set out to obtain and test their facts largely by experiment, thus differentiating this from all previous expeditions. Mr. Steers's main work is published in the Geographical Journal, wherein he considers the formation of the Great Barrier Reef. He accepts the view that there was a post-glacial rise of sea-level, the coast platform having been formed largely by low-level Pleistocene abrasion, this following on downfaulting of a peneplain, composed of Pre-Tertiary rocks.

Dr. Stephenson contributes a happy report containing the outlines of the "Development and the Formation of Colonies in Pocillopora and Porites". He also, assisted by some members of his party, writes a long account of Low Isles and other lagoon reefs, and of one piece of the Barrier Reef. According to Miss Marshall and Dr. Orr's borings, Low Isles reef is a mere veneer of corals and other organisms covering a mud bank (NATURE, $129,141 ; 1932)$. It has a very different foundation from any coral reef visualised by Darwin or any other student of the formation of coral reefs. Dr. Stephenson states that the organisms are extending the surface of the reef outwards, presumably debris being laid down in the waters around in such a way that this outgrowth is assisted. The reef itself was formed as one or more reef patches of a type described as "made of dead boulders and masses of coral with sand between and the surface . . . very irregular and full of complex holes and crevices". The slope to the barrier lagoon is " covered by fixed blocks of dead coral of varying shape" and is illustrated by useful sections. "As the depths of the water increases they tend to become higher, and many of them form very large mounds", the tops often exposed at low water. Their sides are $20 \mathrm{ft}$. or more deep, and corals grow " on top of them and a little below the top". Nearer the shore they give place to a rugged area " covered by fixed blocks of dead coral ". These perpendicular mounds seem to resemble those in the "zone of coral heads" on the lagoon side of Yonge Reef in the barrier series and formerly described in similar places by Surgeon Paradice, who is not referred to. Where I have seen similar structures they were in decay or stationary, and I await further evidence that they have been built

No. 3264, VoL. 129] 